\title{
SOSIALISASI PENCEGAHAN KENAKALAN REMAJA DEMI TERWUJUDNYA GENERASI MUDA YANG BERKUALITAS DAN BERDAYA SAING MENUJU INDONESIA EMAS 2045 DI DESA KARANGMOJO, JOMBANG, JAWA TIMUR
}

\author{
Imanuel Adhitya Wulanata Chrismastianto', Melki Vanriel ${ }^{2}$, M. Azwar Anas ${ }^{3}$ \\ ${ }^{1}$ Universitas Pelita Harapan Tangerang \\ ${ }^{2}$ Universitas Negeri Malang \\ ${ }^{3}$ Universitas Negeri Malang
}

imanuel.wulanata@uph.edu,melki.jrs@gmail.com, azwaranas321@gmail.com

\begin{abstract}
Abstrak
Kenakalan remaja merupakan bentuk aktualisasi perilaku menyimpang yang dilakukan oleh para remaja dan berpotensi menimbulkan keresahan dalam kehidupan bermasyarakat. Salah satu bentuk kenakalan remaja yang dimaksud adalah penyalahgunaan narkotika, psikotropika, dan zat adiktif lainnya. Berkaitan dengan permasalahan tersebut, diperlukan upaya pencegahan secara masif melalui kegiatan sosialisasi yang dilakukan oleh dosen sebagai pembicara dengan melibatkan peran mahasiswa yang mengikuti Kuliah Kerja Nyata (KKN). Adapun kegiatan ini bertujuan untuk melakukan pencegahan kenakalan remaja terhadap penyalahgunaan narkotika, psikotropika, dan zat adiktif lainnya. Kegiatan ini dilakukan di Desa Karangmojo, Jombang, Jawa Timur bekerjasama dengan sejumlah mahasiswa KKN Fakultas Ilmu Pendidikan, Program Studi Pendidikan IPS, Universitas Negeri Malang, didukung oleh LPPM Universitas Negeri Malang, aparatur desa Karangmojo, serta Kanit Babinkamtibmas dari pihak kepolisian sektor Plandaan. Kegiatan ini dihadiri oleh 35 peserta dari kalangan pelajar dengan rentang usia sekolah SD, SMP, dan SMA serta 15 mahasiswa program KKN Universitas Negeri Malang. Metode yang digunakan untuk penyampaian materi sosialisasi melalui ceramah interaktif, diskusi kelompok, desain poster kreatif, serta presentasi poster kreatif yang dilakukan oleh setiap kelompok peserta. Hasil dari kegiatan ini adalah para peserta telah menunjukkan komitmen melalui ide yang dituangkan dalam poster kreatif dan refleksi yang disampaikan dalam kelompok diskusi, sehingga mereka dapat dicegah untuk tidak menyalahgunakan narkotika, psikotropika, dan zat adiktif lainnya ketika berelasi dengan masyarakat.
\end{abstract}

Kata Kunci : Sosialisasi, pencegahan, kenakalan remaja, generasi muda

\section{PENDAHULUAN}

Di era yang modern seperi saat ini, masyarakat dapat begitu mudah memperoleh segala hal dengan memanfaatkan perkembangan teknologi dan informasi. Hal ini dapat menimbulkan berbagai masalah di masyarakat khususnya di kalangan remaja saat ini, misalnya penyalahgunaan narkoba. Kenakalan remaja muncul ke kehidupan saat ni dengan bentuk yang sangat variatif dan sangat memprihatinkan. Masalah penyalahgunaan narkoba mempunyai ruang lingkup yang sangat luas dan kompleks baik dari sudut medik, psikiatri, kesehata jiwa, maupun psikososial. Pengguna narkoba dapat merusak sebuah tatanan baik dalam keluarga maupun dalam masyarakat, bahkan hal inipun dapat mengancam kelangsungan pembangunan dan masa depan bangsa Indonesia. Anak-anak remaja jaman sekarang banyak yang memiliki sifat yang bisa dikatakan sebagai penyakit social dimana penyakit 
social yang disebabkan adanya suatu pengaruh pergaulan yang ada di tengah masyarakat, sehingga anak-anak remaja banyak yang melakukan perbuatan yang negative bagi dirinya sendiri maupun bagi masyarakat sekitar (Norma Payung Mallisa, 2017). Anak yang demikian disebabkan karena kurangnya mendapatkan perhatian dari orang tua mereka, sehingga merekapun memiliki suatu sikap yang terlalu agresif sehingga melakukan banyak hal-hal yang negatif.

Dengan begitu banyak masalah seperti yang dijelaskan di atas, dibutuhkan sebuah terobosan untuk mendidik dan membekali generasi muda agar tidak terjerumus ke pergaulan yang salah. Betapa pentingnya program penguatan pendidikan karakter yang berpedoman pada Perpres Nomor 87 Tahun 2017 agar permasalahan seperti itu tidak akan terulang lagi. Jika melihat kembali sejarah Indonesia, Ir. Soekarno dalam pidatonya bahwa bangsa Indonesia harus dibangun dengan mendahulukan pembangunan karakter (character building) sebagai landasan kokoh perjuangan mengisi kemerdekaan bangsa (Leya, 2016). Ada banyak hal dalam melakukan pemberdayaan sumber daya manusia saat ini, misalnya dalam ruang lingkup pendidikannya. Pengembangan SDM melalui pendidikan adalah salah satu kunci untuk mencapai kemajuan bangsa, karena menurut pernyataan yang tercantum dalam Rencana Pembangunan Jangka Menengah Nasional 2015-2019, upaya dalam membangun bangsa yang benar-benar maju dan modern adalah melalui karya pendidikan (Chaniago, 2014). Pendidikan dipandang berperan dalam mengatasi krisis moral karena pendidikan merupakan sebuah usaha atau proses yang ditujukan untuk membina kualitas sumber daya manusia seutuhnya (Elmubarok, 2008).

Seperti yang sudah diketahui, bahwa pemerintah Indonesia saat ini tengah mempersiapkan generasi emas 2045, dimana generasi yang ingin dicapai yaitu generasi yang maju, beradap, dan berkarakter. Hal ini pun senada dengan apa yang tertuang dalam UU Nomor 20 Tahun 2003 tentang Sisdiknas pasal 3 yang menyebutkan bahwa, " Pendidikan nasional berfungsi mengembangkan kemampuan dan membentuk karakter serta peradaban bangsa yang bermartabat dalam rangka mencerdaskan kehidupan bangsa" (Hidayat, 2016). Hal ini menunjukkan bahwa membangun karakter bukan sekedar berbicara mengenai sikap dan perilaku yang dimiliki seseorang, namun leih pada peran aktifnya dalam melakukan fungsi pembangunan suatu bangsa. Hal inipun menunjukkan bahwa pendidikan karakter sangat berperan penting dalam mempersiapkan SDM yang berkarakter agar mampu berkontribusi secara aktif dalam pembangunan nasional yang berkelanjutan menuju Indonesia yang damai, adil, dan sejahtera.

Oleh sebab itu, berdasarkan paparan di atas, mahasiwa KKN UM di desa Karangmojo, Plandaan, Jombang melakukan program kerja sosialisasi terkait kenakalan remaja yang tujuannya untuk memberikan bekal kepada remaja desa Karangmojo supaya bisa menjadi generasi anti narkoba dan bisa berdaya saing demi kemajuan desa Karangmojo dan menuju Indonesia Emas 2045.

\section{METODE}

Rangkaian kegiatan mulai dari awal sampai terlaksananya acara seminar ini adalah: 1) melakukan koordinasi dengan perangkat desa perihal kenakalan remaja apa saja yang sering terjadi di desa Karangmojo, selain melakukan koordinasi dengan perangkat, mahasiswa juga melakukan koordinasi dengan pihak Polsek Plandaan, 2) melakukan koordinasi dengan pembicara yang berasal dari Universitas Pelita Harapan, tangerang. Dalam hal ini mahasiswa membicarakan terkait topik acara dan konsep acara yang akan dilaksanakan. 3) pada saat kegiatan dimulai, ada beberapa rangkaian acara dimana acara dibuka oleh perangkat dan pihak Polsek Plandaan, kemudian pemateri langsung memberikan materi yang telah dipersiapkan. Ada 2 sesi dalam acara ini, yang pertama sesi pencegahan kenakalan remaja, yang kedua adalah sesi motivasi kuliah.

Banyak hal yang perlu di persiapkan menuju Indonesia emas 2045. Salah satunya adalah pemberdayaan generasi muda. Generasi muda saat ini sangat memprihatinkan dimana karakter mereka mulai runtuh karena banyaknya pergaulan-pergaulan salah akibat kemajuan jaman. Diperlukan kesadaran semua pihak untuk membentuk generasi muda yang berkarakter guna mewujudkan generasi yang berdaya saing. Karakter menurut Pusat Bahasa Depdiknas adalah bawaan, hati, jiwa, kepribadian,

$$
\text { Pendidikan }
$$


budi pekerti, perilaku, personalitas, sifat, tabiat, tempramen, dan watak. Adapun berkarakter adalah berkepribadian, berperilaku, bersifat, bertabiat, dan berwatak (Zubaedi, 2011).

\section{HASIL DAN PEMBAHASAN}

\section{Ruang Lingkup Kegiatan PkM}

Desa Karangmojo merupakan salah satu Desa yang terletak di Kecamatan Plandaan. Secara umum karakteristik wilayah Desa Karangmojo dapat dilihat dari aspek fisik yang meliputi letak, luas, topografi dan kondisi iklim. Desa Karangmojo merupakan Desa yang terletak $\pm 1,5 \mathrm{~km}$ dari pusat Pemerintahan Kecamatan Plandaan. Desa Karangmojo, Kecamatan Plandaan, Kabupaten Jombang memiliki banyak potensi yang belum diberdayakan. Oleh karenanya kami merasa terdorong untuk mengabdikan ilmu yang kami miliki melalui program pemberdayaan dan pengembangan potensi sumber daya manusia dan sumber daya alam yang ada. Kegiatan Kuliah Kerja Nyata (KKN) yang dilakukan mahasiswa diharapakan dapat memberikan dampak positif kepada masyarakat secara umum khususnya pendidikan. Sehingga dengan memberikan dampak positif bagi kedua belah pihak, yaitu bagi masyarakat sebagai mitra belajar dan bagi mahasiswa itu sendiri, dengan demikian akan terwujudnya kesejahteraan, kemoralan dan keagamaan.

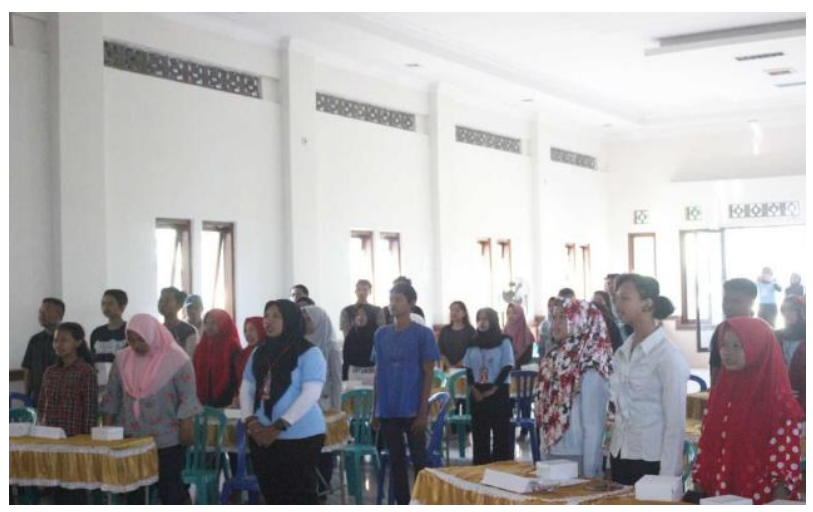

Gambar 1. Para peserta, panitia, dan para pembicara menyanyikan lagu Indonesia Raya.

\section{Materi Kegiatan PkM}

Di era yang modern seperi saat ini, masyarakat dapat begitu mudah memperoleh segala hal dengan memanfaatkan perkembangan teknologi dan informasi. Hal ini dapat menimbulkan berbagai masalah di masyarakat khususnya di kalangan remaja saat ini, misalnya penyalahgunaan narkoba. Kenakalan remaja muncul ke kehidupan saat ni dengan bentuk yang sangat variatif dan sangat memprihatinkan. Remaja memiliki karakteristik yang rentan terkena Narkoba. Salah satunya remaja sangat mudah dipengaruhi kawan, rasa ingin tahu dan ingin coba-coba itulah yang bisa mendorong mereka terjerumus dan terjebak dengan Narkotika, psikotropika, dan zat adiktif (NAPZA), atau jenis obat terlarang lainnya. Obat-obatan ini biasanya digunakan di ruang lingkup medis dengan aturan dari dokter. Akan tetapi jika digunakan tanpa pembatasan dan pengawasan yang seksama dapat menimbulkan ketergantungan serta dapat membahayakan kesehatan dan jiwa pemakainya. Usia remaja adalah usia yang rentan terhadap Narkoba.

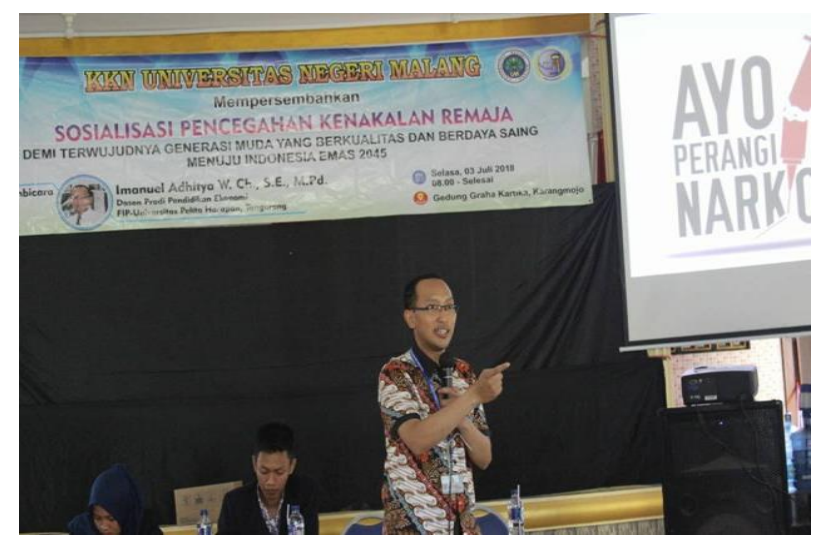

Gambar 2. Keynote speaker menyampaikan materi sosialisasi.

Dampak narkoba jika di salah gunakan memang sangatlah berbahaya bagi remaja. Narkoba dapat merusak kesehatan manusia baik secara fisik, emosi, maupun perilaku pemakainya. Walaupun semua kecenderungan itu wajar-wajar saja, tetapi hal itu biasnya juga memudahkan seseorang untuk terdorong menyalahgunakan narkoba. Data menunjukkan bahwa jumlah pengguna narkoba yang paling banyak adalah kelompok usia remaja hingga dewasa. Masalah menjadi lebih gawat lagi bila penggunaan narkoba, para pemuda tertular dan menularkan HIV/AIDS di kalangan pemuda. Hal ini telah terbukti dari pemakaian narkoba melalui jarum

$$
\text { Pendidikan }
$$


suntik secara bergantian. Bangsa ini akan kehilangan generasai muda yang sangat banyak akibat penyalahgunaan narkoba dan merebaknya HIV/AIDS. Kehilangan generasi muda sama dengan kehilangan sumber daya manusia bagi bangsa dan negara.

Dengan kondisi tersebut, kami selenggarakan kegiatan Penyuluhan Narkoba dikalangan Generasi Muda guna menjadikan pemuda remaja desa Karangmojo yang berdaya saing di era globalisasi dan untuk mempersiapkan Indonesia Emas 2045. Kegiatan ini merupakan sebuah control social yang bersifat preventif dimana kegiatan ini bertujuan untuk mencegah terjadinya tindakan penyalahgunaan narkoba di kalangan remaja desa Karangmojo, Plandaan, Kabupaten Jombang. Kegiatan ini diikuti oleh 35 anak muda di Desa Karangmojo, yang dibuka secara resmi oleh perangkat desa dan perwakilan dari Polsek Plandaan. Kegiatan sosialisasi kenakalan remaja ini sendiri di isi oleh pemateri dari dosen Universitas Pelita Harapan Tangerang, Bapak Imanuel Adhitya Wulanata Ch., S.E., M.Pd.

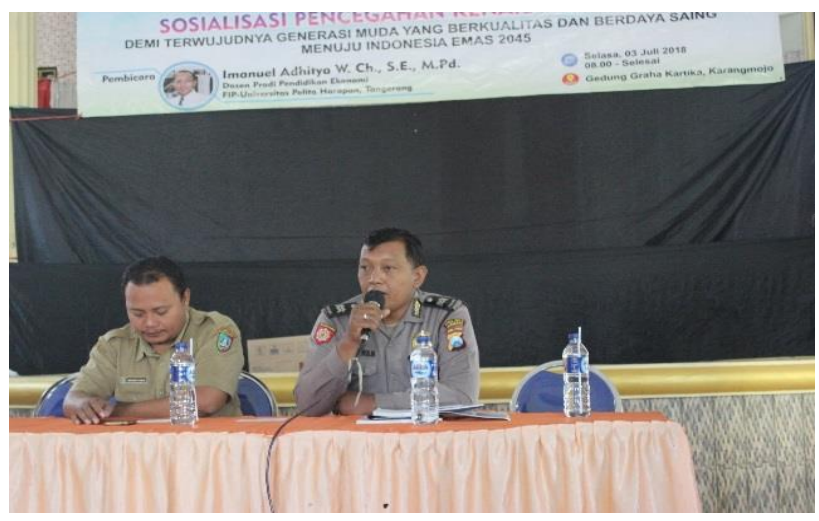

Gambar 3. Kanit Babinkantibmas Polsek Plandaan memberikan kata sambutan.

Kegiatan yang dilakukan yaitu penyampaian materi oleh pembicara mengenai kenakalan remaja, yang terjadi di Indonesia pada masa kini, penyampaian materi mengenai bahaya mengkonsumsi narkoba. Setelah penyampaian materi selesai di lanjutkan dengan pembuatan poster mengenai bentuk ekspresi penolakan kenakalan remaja oleh para peserta sosialisasi. Tidak hanya sosialisasi kenakalan remaja saja pembicara juga menambahkan sesi penguatan motivasi bagi para remaja agar para remaja di desa Karangmojo dapat meningkatkan keinginannya untuk melanjutkan ke jenjang perkuliahan. Dari hasil yang di dapatkan dari proker ini peserta sangat berantusias dalam mengikuti kegiatan sosialisasi yang diadakan oleh mahasiswa KKN Universitas Negeri Malang.

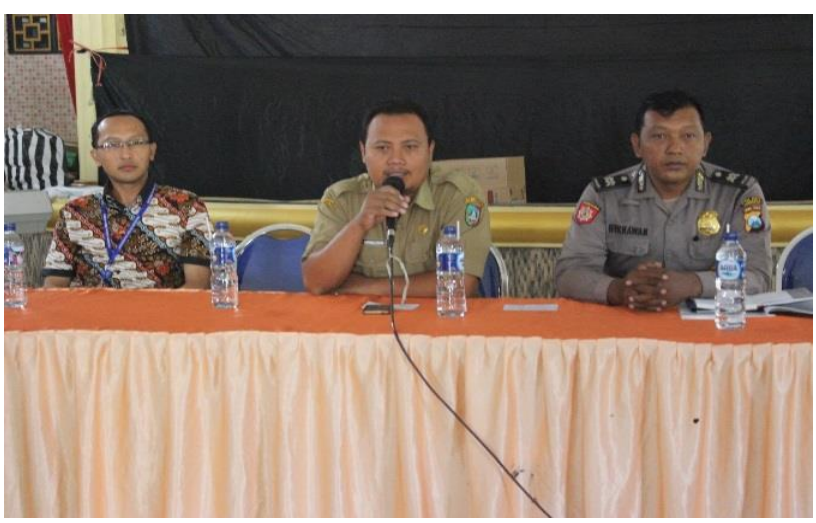

Gambar 3. Perwakilan Perangkat Desa Karangmojo memberikan kata sambutan.

Setelah diadakannya kegiatan ini para remaja di desa karangmojo menyalurkan penolakan kenakalan remaja melalui pembuatan poster. Selain itu, kegiatan inipun mendapat apresiasi yang positif dari Kapolsek Plandaan. Beliau pun sangat senang dengan diadakannya sosialisasi terkait kenakalan remaja ini, karena di desa Karangmojo sendiri merupakan suatu daerah yang rawan terserang narkoba dan sudah banyak dari anak muda sana tertangkap akibat penyalahgunaan narkoba maupun mengedarkan narkoba.

\section{Evaluasi Kegiatan PkM}

Hasil evaluasi dari para peserta yang berpartisipasi dalam kegiatan sosialisasi kenakalan remaja ini cukup positif. Para peserta merasa bahwa materi yang telah disampaikan oleh pemateri sangatlah berguna dan cara penyampaian materi sosialisasi oleh pemateri juga dilakukan dengan cara yang menyenangkan, inovatif dan bersifat interaktif serta peserta diajak untuk banyak diskusi. Selain itu, evaluasi dari perangkat desa dan pihak Polsek plandaan dalam kegiatan inipun juga positif. Mereka sangat mengapresiasi dengan kegiatan sosialisasi kenakalan remaja yang diadakan oleh mahasiswa KKN Universitas Negeri Malang. Selanjutnya, para remaja dan para partisipan yang terlibat berharap jika 
pengadaan sosialisasi bisa sering dilakukan. Hal ini bertujuan untuk menambah wawasan akan kenakalan remaja yang sering terjadi dan bagaimana cara mengatasinya. Selain itu, pembuatan poster yang semenarik mungkin juga turut membantu dalam menyebarluaskan bahaya dari narkoba dan kenakalan remaja lain yang terjadi.

\section{KESIMPULAN}

Kenakalan Program kerja Sosialisasi Pencegahan Remaja yang dilaksanakan Selasa, 3 Juli 2018 dapat dikatakan berjalan dengan baik. Rangkaian kegiatan yang dilaksanakan sudah sesuai dengan yang telah di jadwalkan. Antusiame para remaja desa Karangmojo dalam pelaksanaannya sangat tinggi sehingga dapat menjadi tolak ukur keberhasilan dari program kerja sosialisasi pencegahan kenakalan remaja. Selain itu, program ini pun mendapat apresiasi yang sangat baik dari pihak desa dan dari pihak Polsek Plandaan. Pendekatan yang dilakukan panitia kepada warga masyarakat sebelum pelaksanaan kegiatan membuat program kerja ini dapat terlaksana dengan baik.

\section{UCAPAN TERIMAKASIH}

Terima kasih kepada Kepala Desa dan seluruh Perangkat Desa Karangmojo yang telah mendukung acara ini, sehingga bisa berjalan dengan lancar. Terima kasih juga kepada Kapolsek dan Kanit Babinkantibmas Kecamatan
Plandaan yang turut mendukung kegiatan sosialisasi kenakalan remaja ini, serta kepada pihak LP2M Universitas Negeri Malang yang telah membantu dalam bentuk dana kegiatan, sehingga acara ini bisa berjalan dengan lancar.

\section{REFERENSI}

Chaniago, A. 2014. Melakukan revolusi karakter bangsa, Buku Rencana Pembangunan Jangka Menengah Nasional (RPJMN) 2015-2019. http://www.social-protection.org/

Leya, 2016. Pembangunan karakter bangsa, Tajuk Indonesia Satu, http://indonesiasatuco/

Mustakim, B 2012. Generasi emas dengan karakter emas, MPA 309. http://jatim.kemenag.go.id/

Hidayat, S. 2016. Menanamkan nilai-nilai karakter melalui inovasi pembelajaran berbasis karakter dalam menghadapi masyarakat ekonomi asean. eproceding Seminar Nasional Inovasi Pendidikan FKIP UNS hal. 374-381. http://jurnal.fkip.uns.ac.id/

Norma Payung Mallisa. 2017. Bahaya Narkoba Terhadap Kehidupan Sosial Keberagaman Remaja (Studi Kasus di Antang Raya Kelurahan Antang Kecamatan Manggala Kota Makasar). SKRIPSI. 